\title{
PENGARUH SUBSTITUSI TEPUNG AMPAS KELAPA TERHADAP NILAI INDEKS GLIKEMIK, BEBAN GLIKEMIK, DAN TINGKAT KESUKAAN ROTI
}

\author{
Rayyani Zaena Dini, Ninik Rustanti ${ }^{*}$ \\ Program Studi Ilmu Gizi Fakultas Kedokteran Universitas Diponegoro \\ Jl.Dr.Sutomo No.18, Semarang, Telp (024) 8453708, Email : gizifk@undip.ac.id
}

\begin{abstract}
Background: Diabetes Mellitus type II is very closely related to the lifestyle and it also is progressive. Nutritional strategy to reduce the risk of complication is controlling blood glucose. This strategy can be done by choosing foods with low glycaemic index (GI), but still consider the amount of carbohydrates being consumed. Utilization of coconut-residue flour processed into bread can produce a product with lower GI than regular bread.

Objective: Analyzed the glycaemic index, glycaemic load, and preference level of bread which substituted with coconut-residue flour.

Method: The completely randomized single-factor experimental design on the concentration of coconut-residue flour $(0 \%, 10 \%$, and 20\%) which substituted to the bread to know its effect on the glycaemic index, glycaemic load, and preference level of bread. The glycaemic index and glycaemic load's data was analyzed by One Way ANOVA test, while the preference level's data was analyzed by Friedman test.

Results: Glycaemic index that produced ranges from 39,85 - 66,55\%, while glycaemic load that produced ranges from 14,50 - 24,38. The substitution of coconut-residue flour significantly effect on the glycaemic index and glycaemic load of bread. The preference level test showed that bread which is substituted with coconut-residue flour had neutral to like for color, aroma, texture, and flavor.

Conclusion: Bread which substituted with $20 \%$ of coconut-residue flour produced the lowest glycaemic index and glycaemic load. Bread which substituted with coconut-residue flour have a lower level of preference than the bread without substitution of coconut flour.
\end{abstract}

Keyword : Coconut-residue flour; bread; glycaemic index; glycaemic load; preference level

\begin{abstract}
ABSTRAK
Latar Belakang: Diabetes Melitus tipe II merupakan tipe diabetes yang sangat berhubungan erat dengan pola hidup dan bersifat progresif, sehingga dalam penatalaksanaannya diperlukan kontrol gula darah agar keadaan tidak memburuk dan menurunkan risiko komplikasi. Upaya ini dapat dilakukan melalui pemilihan makanan dengan indeks glikemik (IG) rendah, namun tetap memperhatikan jumlah karbohidrat yang dikonsumsi. Pemanfaatan tepung ampas kelapa yang diolah menjadi roti dapat menghasilkan roti dengan nilai indeks glikemik yang lebih rendah daripada roti biasa.

Tujuan: Menganalisis nilai indeks glikemik, beban glikemik, dan tingkat kesukaan roti yang disubstitusi dengan tepung ampas kelapa.

Metode: Penelitian eksperimental acak lengkap satu faktor pada konsentrasi tepung ampas kelapa (0\%, 10\%, dan $20 \%)$ yang disubstitusikan pada roti untuk mengetahui pengaruhnya terhadap nilai indeks glikemik, beban glikemik, dan tingkat kesukaan roti. Data nilai indeks glikemik dan beban glikemik dianalisis menggunakan uji One Way ANOVA, sedangkan data tingkat kesukaan dianalisis menggunakan uji Friedman.

Hasil: Indeks glikemik yang dihasilkan berkisar antara 39,85 - 66,55 \%, sedangkan beban glikemik berkisar antara 14,50 - 24,38. Substitusi tepung ampas kelapa berpengaruh secara nyata terhadap indeks glikemik dan beban glikemik. Uji tingkat kesukaan terhadap warna, aroma, tekstur, dan rasa pada roti yang disubstitusikan dengan tepung ampas kelapa memperoleh penilaian netral hingga suka.

Kesimpulan: Roti substitusi 20\% tepung ampas kelapa memiliki IG dan BG terendah. Roti substitusi tepung ampas kelapa memiliki tingkat kesukaan yang lebih rendah daripada roti tanpa substitusi tepung ampas kelapa.

Kata kunci: Tepung ampas kelapa; roti; indeks glikemik; beban glikemik; tingkat kesukaan
\end{abstract}

\section{PENDAHULUAN}

Diabetes Melitus (DM) merupakan suatu penyakit dengan karakteristik hiperglikemia yang terjadi karena kelainan sekresi insulin, kerja insulin, atau kedua-duanya. ${ }^{1}$ Berdasarkan laporan Riset Kesehatan Dasar (Riskesdas) tahun 2007, prevalensi DM di daerah urban Indonesia untuk usia di atas 15 tahun sebesar 5,7\% ${ }^{2}$. Diantara tipetipe diabetes melitus, DM tipe II merupakan tipe penyakit diabetes yang paling banyak diderita. DM tipe II sangat berhubungan erat dengan pola hidup dan bersifat progresif, sehingga dalam penatalaksanaannya diperlukan kontrol gula darah 
agar keadaan tidak memburuk dan menurunkan risiko komplikasi ${ }^{3}$.

Salah satu cara untuk mengontrol gula darah adalah dengan pengaturan diet. Upaya ini dapat dilakukan melalui pendekatan indeks glikemik (IG) pangan. Berdasarkan penelitian dengan subjek normal dan diabetes menunjukkan IG rendah terbukti menurunkan glukosa post-prandial, respon insulin serta memperbaiki glukosa darah keseluruhan dan konsentrasi lipid ${ }^{4,5}$. World Health Organization (WHO) merekomendasikan konsumsi makanan dengan IG rendah untuk membantu meningkatkan pengendalian glukosa darah, namun tetap memperhatikan jumlah karbohidrat yang dikonsumsi. ${ }^{6}$

Indeks glikemik pangan dapat dipengaruhi oleh beberapa faktor, diantaranya yaitu rasio amilosa dan amilopektin, gula dan daya osmotik, kandungan serat pangan, pati resisten, lemak, protein, dan zat anti gizi, serta proses pengolahan makanan, meliputi ukuran partikel dan gelatinasi pati $^{3,7}$. Prinsip diet IG rendah yaitu terdiri dari jenis makanan yang mengandung karbohidrat kompleks dan tinggi serat ${ }^{7}$.

Salah satu bahan makanan yang tinggi serat ialah ampas kelapa. Ampas kelapa dapat diolah menjadi tepung yang kemudian dapat dimanfaatkan sebagai bahan baku dalam industri makanan, misalnya produk $\operatorname{roti}^{8,9}$. Namun, pemanfaatan ampas kelapa menjadi bahan pangan, yaitu tempe bongkrek, sering dihubungkan dengan kejadian keracunan makanan karena bakteri Pseudomonas cocovenenans. Bakteri ini dapat menghasilkan dua racun, yaitu toxoflavin dan asam bongkrek $^{10}$. Asam bongkrek merupakan zat yang sangat aktif terhadap Saccharomyces cereviseae, sehingga kontaminasi bakteri ini dapat ditandai dengan hasil fermentasi yang tidak baik ${ }^{16}$.

Alasan mengapa keracunan makanan karena bakteri ini hanya dapat muncul pada beberapa jenis khusus makanan masih belum jelas diketahui penyebabnya. Namun, salah satu penelitian yang pernah dilakukan menunjukkan bahwa jenis asam lemak suatu makanan berperan penting dalam pembentukan racun ini. Penelitian tersebut membuktikan bahwa asam lemak yang dapat memicu timbulnya racun ini adalah asam lemak jenuh yaitu asam laurat, miristat, palmitat, serta asam lemak tak jenuh yaitu asam oleat, linoleat, dan linolenat ${ }^{11}$. Asam lemak yang dihasilkan oleh tepung ampas kelapa ialah asam butirat, asetat, dan propionat $^{16}$. Hal tersebut merupakan kondisi yang tidak mendukung untuk munculnya racun karena bakteri ini, sehingga tepung ampas kelapa aman untuk dikonsumsi.

Untuk menghambat pertumbuhan bakteri Pseudomonas cocovenenans juga dapat dilakukan dengan penambahan 3\% $\mathrm{NaCl}$ pada medium ampas kelapa. Suhu optimum untuk pertumbuhan bakteri ini berkisar pada $30^{\circ} \mathrm{C}-37^{\circ} \mathrm{C}$, bakteri ini tidak tumbuh pada suhu $4^{\circ} \mathrm{C}$ dan $45^{\circ} \mathrm{C}$, sehingga dalam pencegahannya juga dapat dilakukan dengan memberikan perlakuan suhu di atas $45^{\circ} \mathrm{C}$ pada medium ampas kelapa. ${ }^{10,12,13}$

Salah satu kelebihan tepung ampas kelapa adalah kandungan seratnya yang cukup tinggi yaitu $60,9 \%$, dimana kandungan serat larut air sebanyak $3,8 \%$ dan serat tidak larut air sebanyak $56,8 \%{ }^{15}$. Salah satu faktor yang mempengaruhi IG adalah serat, oleh karena itu IG tepung ampas kelapa juga rendah. Pada penelitian sebelumnya telah dilakukan substitusi tepung ampas kelapa pada biskuit (15\%) dan menghasilkan IG sebesar 43,4; brownies (25\%) menghasilkan IG 42,7; dan makaroni $(25 \%)$ menghasilkan IG $32,4^{16}$. Dari ketiga hasil penelitian ini, dapat disimpulkan bahwa substitusi tepung ampas kelapa dapat menghasilkan makanan dengan nilai IG yang rendah. Oleh karena itu, dilakukan penelitian terhadap nilai indeks glikemik dan beban glikemik, serta tingkat kesukaan pada roti yang disubstitusi dengan tepung ampas kelapa.

\section{METODA}

Penelitian yang dilakukan merupakan penelitian dalam bidang food production. Penelitian dilakukan pada bulan Agustus hingga Oktober di Laboratorium Pangan Universitas Muhamadiyah Semarang untuk membuat roti substitusi tepung ampas kelapa dan di lingkup Universitas Diponegoro untuk menguji indeks glikemik dan tingkat kesukaan.

Penelitian ini merupakan penelitian eksperimental dengan rancangan acak lengkap satu faktor pada konsentrasi tepung ampas kelapa $(0 \%$, $10 \%$, dan 20\%) yang disubstitusikan pada roti untuk mengetahui pengaruhnya terhadap nilai indeks glikemik, beban glikemik, dan tingkat kesukaan roti.

Roti dibuat menggunakan bahan baku tepung terigu protein tinggi, tepung ampas kelapa, gula khusus DM (sorbitol 1,97 g dan sukrolase 9,8 $\mathrm{mg}$ ), ragi instan, susu skim cair, kuning telur, air dingin, garam, dan margarin ${ }^{17}$. Cara pembuatan tepung ampas kelapa adalah ampas kelapa yang telah dipisahkan santan dan minyaknya dicuci bersih, lalu dipress, dan diblanching pada air 
mendidih yang telah ditambahkan $3 \% \mathrm{NaCl}$ selama \pm 3 menit kemudian dihilangkan kadar airnya dengan menggunakan mesin spinner, setelah itu ampas kelapa dikeringkan pada suhu $60^{\circ} \mathrm{C}$ selama 3 hari, digiling, dan diayak dengan ayakan 80 mesh $^{9}$.

Cara pembuatan roti adalah tepung terigu dicampur dengan tepung ampas kelapa, gula, garam, dan ragi instan. Campuran ini lalu diuleni dengan ditambahkan margarin cair, kuning telur, susu cair, dan air dingin sedikit demi sedikit hingga adonan menjadi kalis. Setelah kalis, adonan didiamkan pada tempat yang ditutup dengan kain lembab selama \pm 30 menit. Lalu adonan dipindahkan ke dalam loyang yang telah diolesi margarin dan tepung terigu dan didiamkan kembali selama \pm 90 menit dengan ditutup kain lembab. Adonan yang sudah mengembang dipanggang dalam oven selama 20 menit dengan suhu $200^{\circ} \mathrm{C} .{ }^{17}$

Pada penelitian utama, data yang dikumpulkan adalah nilai indeks glikemik, beban glikemik dan uji organoleptik roti substitusi tepung ampas kelapa. Perhitungan IG menggunakan metode incremental area under the blood glucose response curve (IAUC) ${ }^{18}$. Pengujian ini dilakukan pada 10 orang subjek yang telah berpuasa (kecuali air putih) selama 10 jam. Setelah berpuasa 10 jam, diambil darah kapiler subjek untuk mengukur kadar glukosa darah puasa. Kemudian subjek diminta untuk mengonsumsi pangan uji (glukosa murni serta roti substitusi tepung ampas kelapa dengan persentase $0 \%, 10 \%$, dan 20\%) yang mengandung $50 \mathrm{~g}$ available carbohydrate. Sampel darah subjek diambil setiap 30 menit $(30,60,90$, dan 120 menit) setelah mengonsumsi pangan uji selama $2 \mathrm{jam}^{4,7,19,20}$. Setiap perlakuan dilakukan dengan jarak minimal 3 hari untuk menghindari bias dari setiap makanan yang diujikan ${ }^{18}$. Uji IG dilakukan dengan menggunakan alat tes glukosa darah merek Easy Touch GCU, model ET-301F, produksi Chiuan Rwey Enterprise Co., Ltd.

Data glukosa darah subjek kemudian ditebar pada sumbu X sebagai waktu (menit) dan sumbu Y sebagai kadar glukosa darah. Besarnya IG dihitung dengan membandingkan luas daerah di bawah kurva pangan uji (roti substitusi tepung ampas kelapa) dan pangan standar (glukosa murni), kemudian hasilnya dirata-rata. Luas daerah di bawah kurva dihitung dengan rumus ${ }^{18,20}$ :

$$
\begin{aligned}
& \mathrm{L}=\frac{\Delta 30 \mathrm{t}}{2}+\Delta 60 \mathrm{t}+\frac{(\Delta 30-\Delta 60) \mathrm{t}}{2}+\Delta 90 \mathrm{t}+\frac{(\Delta 60-\Delta 90) \mathrm{t}}{2}+\Delta 120 \mathrm{t}+\frac{(\Delta 90-\Delta 120) \mathrm{t}}{2} \\
& \text { Keterangan : } \\
& \mathrm{L} \quad=\text { luas area dibawah kurva } \\
& \mathrm{t} \quad=\text { interval waktu pengambilan darah (30 menit) } \\
& \Delta 30=\text { selisih kadar glukosa darah } 30 \text { menit setelah beban dengan puasa } \\
& \Delta 60=\text { selisih kadar glukosa darah } 60 \text { menit setelah beban dengan puasa } \\
& \Delta 90=\text { selisih kadar glukosa darah } 90 \text { menit setelah beban dengan puasa } \\
& \Delta 120=\text { selisih kadar glukosa darah } 120 \text { menit setelah beban dengan puasa }
\end{aligned}
$$

Perhitungan beban glikemik (BG) dilakukan dengan mengalikan IG dengan kadar available carbohydrate roti substitusi tepung ampas kelapa yang didapatkan dari hasil uji total gula dan pati ${ }^{7,19,20}$. Uji organoleptik untuk mengetahui tingkat kesukaan panelis terhadap roti substitusi tepung ampas kelapa menggunakan uji hedonik dengan lima skala hedonik, yaitu $1=$ Sangat tidak suka, $2=$ Tidak suka, 3=Netral, 4=Suka, dan 5=Sangat suka. Penilaian uji organoleptik dilakukan pada 25 panelis agak terlatih, mahasiswa Program Studi Ilmu Gizi Fakultas Kedokteran Universitas Diponegoro ${ }^{21,22}$. Data uji IG dan BG yang terkumpul kemudian dianalisis menggunakan uji ANOVA one way dengan derajat kepercayaan 95\%. Sedangkan data hasil uji tingkat kesukaan dianalisis menggunakan uji statistik Friedman dengan derajat kepercayaan $95 \%$. $^{23}$

\section{HASIL}

\section{Karakteristik Subjek}

Subjek terdiri dari 10 orang perempuan yang telah menandatangani informed consent dengan status gizi normal (IMT 18,5 - 22,9 $\mathrm{kg} / \mathrm{m}^{2}$ ) dan GDP antara $70-120 \mathrm{mg} / \mathrm{dl}$, serta umur berkisar antara $20-23 \operatorname{tahun}^{19,20}$. Karakteristik subjek penelitian dapat dilihat pada Tabel 1 . 
Tabel 1. Karakteristik Subjek Penelitian

\begin{tabular}{cccccc}
\hline Subjek & $\begin{array}{c}\text { Umur } \\
\text { (Tahun) }\end{array}$ & $\begin{array}{c}\text { BB } \\
(\mathbf{k g})\end{array}$ & $\begin{array}{c}\text { TB } \\
(\mathbf{c m})\end{array}$ & $\begin{array}{c}\mathbf{I M T}^{*} \\
\left(\mathbf{k g} / \mathbf{m}^{\mathbf{2}}\right)\end{array}$ & $\begin{array}{c}\text { GDP } \\
(\mathbf{m g} / \mathbf{d l})\end{array}$ \\
\hline 1 & 21 & 59 & 163 & 22,18 & 86 \\
2 & 22 & 59 & 162 & 22,52 & 80 \\
3 & 22 & 43,7 & 148 & 19,95 & 80 \\
4 & 22 & 59 & 162 & 22,52 & 86 \\
5 & 22 & 46 & 156 & 18,93 & 89 \\
6 & 22 & 48,3 & 153 & 20,64 & 80 \\
7 & 22 & 41,2 & 147,5 & 18,89 & 76 \\
8 & 22 & 44 & 153 & 18,8 & 89 \\
9 & 22 & 46,6 & 150 & 20,71 & 83 \\
10 & 21 & 57 & 159 & 22,53 & 78 \\
\hline Rata-rata & $\mathbf{2 1 , 8}$ & $\mathbf{5 0 , 8}$ & $\mathbf{1 5 5 , 5}$ & $\mathbf{2 0 , 9}$ & $\mathbf{8 3 , 3 6}$ \\
\hline
\end{tabular}

Berdasarkan Tabel 1. diketahui bahwa ratarata umur subjek adalah 21,8 tahun dengan ratarata IMT sebesar $20,9 \mathrm{~kg} / \mathrm{m}^{2}$ dan GDP $83,36 \mathrm{mg} / \mathrm{dl}$. Hal ini telah sesuai dengan kriteria inklusi subjek.

\section{Penentuan Jumlah Pangan Uji}

Bahan pangan yang akan dinilai indeks glikemiknya adalah roti substitusi tepung ampas kelapa dengan persentase $0 \%, 10 \%$, dan $20 \%$, sedangkan bahan pangan standar yang akan digunakan sebagai pembandingnya adalah glukosa murni. Masing-masing bahan harus mengandung $50 \mathrm{~g}$ available carbohydrate yang dapat diketahui dari kandungan gula total dan pati bahan pangan tersebut ${ }^{18-20}$. Karena bahan pangan standar yang digunakan adalah glukosa murni, sehingga jumlah berat bahan pangan standar yang diberikan sebanyak $50 \mathrm{~g}$, sedangkan untuk bahan pangan uji dapat dilihat pada Tabel 2.

Tabel 2. Penentuan Jumlah Pangan Uji yang Setara dengan 50 g Available Carbohydrate

\begin{tabular}{ccccc}
\hline $\begin{array}{c}\text { Roti Substitusi } \\
\text { Tepung Ampas } \\
\text { Kelapa }\end{array}$ & $\begin{array}{c}\text { Pati } \\
(\boldsymbol{\%})\end{array}$ & $\begin{array}{c}\text { Gula } \\
(\boldsymbol{\%})\end{array}$ & $\begin{array}{c}\text { Available } \\
\text { Carbohydrate* } \\
(\boldsymbol{\%})\end{array}$ & $\begin{array}{c}\text { Berat Roti** } \\
\text { (g/subjek) }\end{array}$ \\
\hline $0 \%$ & 48,64 & 68,605 & 122,109 & 41 \\
$10 \%$ & 42,595 & 65,565 & 112,4195 & 44,5 \\
$20 \%$ & 54,11 & 61,797 & 121,314 & 40,5 \\
\hline
\end{tabular}

Keterangan ${ }^{20}$ :

$*$ available carbohydrate $=$ gula total $+(1,1 \mathrm{x}$ pati $)$

**jumlah sampel $=\frac{50 \mathrm{~g}}{\text { available carbohydrate }} \times 100$

\section{Indeks Glikemik (IG) dan Beban Glikemik} (BG)

a. Kadar Glukosa Darah

Rata-rata hasil glukosa darah subjek terhadap pemberian glukosa murni dan roti substitusi tepung ampas kelapa dapat dilihat pada Tabel 3 .

Tabel 3. Hasil Rata-rata Kadar Glukosa Darah (mg/dl)

\begin{tabular}{lccccc}
\hline \multirow{2}{*}{ Bahan Pangan } & \multicolumn{5}{c}{ Waktu (menit) } \\
\cline { 2 - 6 } & $\mathbf{0}$ & $\mathbf{3 0}$ & $\mathbf{6 0}$ & $\mathbf{9 0}$ & $\mathbf{1 2 0}$ \\
\hline Glukosa murni & 83,3 & 159,1 & 134,6 & 112,6 & 91,5 \\
Substitusi 0\% & 89,3 & 148,6 & 118,9 & 102,6 & 91,7 \\
Substitusi 10\% & 88,5 & 119,9 & 110,5 & 101,4 & 90,8 \\
Substitusi 20\% & 86,1 & 116,1 & 105,4 & 96,7 & 89,6 \\
\hline
\end{tabular}

Berdasarkan Tabel 3. diketahui bahwa puncak kenaikan kadar gula darah terjadi pada menit ke-30 setelah makan dan menurun secara bertahap pada menit-menit selanjutnya. 
Puncak kenaikan kadar gula darah menurun seiring dengan penambahan substitusi tepung ampas kelapa dengan kenaikan tertinggi yaitu glukosa murni dan terendah.yaitu roti substitusi tepung ampas kelapa $20 \%$. b. Indeks Glikemik

Indeks glikemik masing-masing roti substitusi tepung ampas kelapa diperoleh dari hasil rata-rata IG 10 orang subjek. Hasilnya dapat dilihat pada Tabel 4.

Tabel 4. Indeks Glikemik Roti Substitusi Tepung Ampas Kelapa

\begin{tabular}{lcccc}
\hline \multicolumn{2}{c}{$\begin{array}{c}\text { Bahan Pangan } \\
\text { Uji }\end{array}$} & $\begin{array}{c}\text { Luas Area di } \\
\text { Bawah Kurva }(\mathbf{c m})\end{array}$ & $\begin{array}{c}\text { Indeks Glikemik } \\
(\mathbf{\%})\end{array}$ & Kategori * \\
\hline $\begin{array}{l}\text { Roti Substitusi 0\% } \\
\text { Roti }\end{array}$ & Substitusi & 3102 & $66,55^{\mathrm{a}} \pm 18,82$ & $\begin{array}{c}\text { Sedang } \\
10 \%\end{array}$ \\
Roti & Substitusi & 2023,5 & $43,91^{\mathrm{b}} \pm 13,94$ & Rendah \\
$20 \%$ & & 1849,5 & $39,85^{\mathrm{b}} \pm 15,05$ & Rendah \\
\hline
\end{tabular}

Keterangan :

Angka yang diikuti huruf superscript berbeda (a,b) menunjukkan beda nyata

*kategori ${ }^{7}$ : IG rendah $(<55)$, IG sedang (55-70), IG tinggi (>70)

Berdasarkan Tabel 4. diketahui bahwa IG tertinggi dengan kategori sedang $(66,55 \%)$ yaitu roti substitusi tepung ampas kelapa $0 \%$ dan IG terendah dengan IG rendah $(39,85 \%)$ yaitu roti substitusi tepung ampas kelapa $20 \%$. c. Beban Glikemik (BG) Hasil perhitungan $\mathrm{BG}$ dapat dilihat pada Tabel 5.

Tabel 5. Nilai Beban Glikemik Roti Substitusi Tepung Ampas Kelapa

\begin{tabular}{|c|c|c|c|c|c|}
\hline $\begin{array}{c}\text { Roti } \\
\text { Substitusi } \\
\text { Tepung } \\
\text { Ampas } \\
\text { Kelapa } \\
\end{array}$ & $\begin{array}{c}\text { Jumlah } \\
\text { Penyajian }^{26} \\
\text { (g) }\end{array}$ & $\begin{array}{c}\text { Available } \\
\text { Carbohydrate } \\
(\%)\end{array}$ & $\begin{array}{c}\text { Available } \\
\text { Carbohydrate/porsi }\end{array}$ & $\begin{array}{c}\text { Beban } \\
\text { Glikemik* }\end{array}$ & Kategori*** \\
\hline $0 \%$ & 30 & 122,11 & 36,63 & $\begin{array}{c}24,38^{\mathrm{a}} \pm \\
6,89\end{array}$ & Tinggi \\
\hline $10 \%$ & 30 & 112,42 & 33,73 & $\begin{array}{c}14,81^{\mathrm{b}} \pm \\
4,84\end{array}$ & Sedang \\
\hline $20 \%$ & 30 & 121,31 & 36,39 & $\begin{array}{c}14,50^{\mathrm{b}} \pm \\
5,48\end{array}$ & Sedang \\
\hline
\end{tabular}

Keterangan :

Angka yang diikuti huruf superscript berbeda $(\mathrm{a}, \mathrm{b})$ menunjukkan beda nyata

$* \mathrm{BG}=\frac{\mathrm{IG} \times \mathrm{jumlah} \text { available carbohydrate per porsi }}{100}$

**Kategori : BG rendah $(<10)$, BG sedang (11-19), BG tinggi $(>20)^{4,20}$

Berdasarkan Tabel 5. BG roti substitusi tepung ampas kelapa 0\% masih tergolong tinggi $(24,38)$, sedangkan roti substitusi tepung ampas kelapa $10 \%$ dan $20 \%$ tergolong sedang $(14,81$ dan 14,50$)$.

\section{Uji Tingkat Kesukaan}

Hasil analisis uji tingkat kesukaan roti substitusi tepung ampas kelapa oleh panelis terhadap warna, aroma, tekstur, serta rasa dapat dilihat pada Tabel 6 .

Tabel 6. Hasil Analisis Uji Tingkat Kesukaan Roti Substitusi Tepung Ampas Kelapa

\begin{tabular}{ccccccccc}
\hline $\begin{array}{c}\text { Roti Substitusi } \\
\text { Tp. Ampas } \\
\text { Kelapa }\end{array}$ & Rerata & Ket & Rerata & Ket & Rerata & Ket & Rerata & Ket \\
\cline { 2 - 8 } & & & & & & & & \\
\hline $\mathbf{0 \%}$ & $4,20^{\mathrm{a}} \pm 0,764$ & Suka & $3,80 \pm 1,000$ & Suka & $4,20^{\mathrm{a}} \pm 0,957$ & Suka & $4,08^{\mathrm{a}} \pm 0,954$ & Suka \\
$\mathbf{1 0 \%}$ & $3,76^{\mathrm{a}, \mathrm{b}} \pm 0,970$ & Suka & $3,68 \pm 0,852$ & Suka & $3,40^{\mathrm{b}} \pm 1,000$ & Netral & $3,72^{\mathrm{a}, \mathrm{b}} \pm 0,792$ & Suka
\end{tabular}




\begin{tabular}{|c|c|c|c|c|c|c|c|}
\hline $3,28^{\mathrm{b}} \pm 0,843$ & Netral & $3,48 \pm 0,872$ & Suka & $3,12^{\mathrm{b}} \pm 0,833$ & Netral & $3,24^{\mathrm{b}} \pm 0,879$ & netral \\
\hline$p=0,001$ & & $p=0,236$ & & $p=0,000$ & & $p=0.002$ & \\
\hline
\end{tabular}

Keterangan : huruf superscript yang berbeda pada parameter menunjukkan beda nyata dari analisis Friedman

Berdasarkan Tabel 6. substitusi tepung ampas kelapa berpengaruh terhadap nilai kesukaan warna, tekstur, dan rasa roti, tetapi tidak berpengaruh secara bermakna terhadap nilai kesukaan aroma roti. Roti yang disubstitusi tepung ampas kelapa memiliki tingkat kesukaan yang lebih rendah dibandingkan dengan roti tanpa substitusi tepung ampas kelapa.

\section{PEMBAHASAN}

\section{Indeks Glikemik dan Beban Glikemik}

Pengujian IG menggunakan glukosa murni sebagai pangan standar dan roti substitusi tepung ampas kelapa $0 \%, 10 \%$, dan $20 \%$ sebagai pangan uji. Seluruh bahan pangan yang diuji setara dengan 50 g karbohidrat yang ditentukan berdasarkan kandungan available karbohidrat. Available karbohidrat menggambarkan kandungan total karbohidrat yang tersedia untuk tubuh sehingga mudah dicerna, diserap, dan dimetabolisme tubuh. ${ }^{20}$

Indeks glikemik merupakan suatu cara untuk memberikan gambaran tentang hubungan antara karbohidrat dalam makanan dengan respon glukosa darah. Pangan yang memiliki IG rendah dapat mengoptimalkan kontrol glikemik pada penderita DM tipe 2 dengan memperlambat absorbsi karbohidrat ${ }^{4}$. Indeks glikemik makanan dapat dikelompokkan menjadi IG rendah $(<55)$, IG sedang (55-75), dan IG tinggi (>75). ${ }^{7}$ Roti yang disubstitusikan dengan tepung ampas kelapa sebanyak $20 \%$ memiliki IG terendah yaitu $39,85 \%$ dan roti tanpa substitusi tepung ampas kelapa memiliki IG tertinggi yaitu $66,55 \%$. IG roti yang disubstitusikan dengan tepung ampas kelapa sebanyak $10 \%$ yaitu $43,91 \%$. Roti substitusi tepung ampas kelapa sebanyak $10 \%$ dan $20 \%$ memiliki nilai IG rendah, sedangkan roti tanpa substitusi tepung ampas kelapa memiliki IG sedang. Hal ini menunjukkan bahwa semakin banyak substitusi tepung ampas kelapa, maka IG roti akan turun.

Hasil penelitian ini sesuai dengan hasil penelitian yang telah dilakukan sebelumnya terhadap sepuluh orang penderita diabetes dan sepuluh orang non diabetes. Masing-masing responden mengonsumsi produk bakery yang diberikan penambahan tepung ampas kelapa dengan jumlah bervariasi. Ditemukan bahwa semakin banyak penambahan tepung ampas kelapa yang diberikan, semakin rendah juga IG dalam makanan tersebut ${ }^{4,16}$. Semakin menurunnya nilai IG mungkin dikarenakan kandungan serat tepung ampas kelapa yang tinggi, sehingga semakin banyak tepung ampas kelapa yang disubstitusikan pada roti maka kandungan serat roti substitusi tepung ampas kelapa pun akan semakin tinggi. Semakin tinggi kandungan serat roti maka IG roti pun akan semakin rendah.

Serat makanan berperan dalam penghambatan penyerapan makanan di dalam saluran pencernaan yang mengakibatkan semakin tinggi kandungan serat suatu makanan maka IG makanan tersebut juga akan semakin rendah ${ }^{7}$. Makanan tanpa kandungan serat pangan menyebabkan pelepasan glukosa yang cepat sehingga membutuhkan banyak insulin untuk mengubah glukosa tersebut menjadi energi. Serat pangan mampu memperlambat penyerapan glukosa dalam usus dan dengan demikian mengurangi kebutuhan insulin. ${ }^{27}$

Pangan IG rendah akan dicerna dan diubah menjadi glukosa secara bertahap dan perlahanlahan, sehingga puncak kadar gula darah juga akan rendah; berarti fluktuasi peningkatan kadar gula relatif pendek. Hal ini sangat penting bagi diabetesi dalam mengendalikan kadar gula darah. Sebaliknya, pangan IG tinggi akan dicerna dan diubah menjadi glukosa dengan cepat. Hal ini sangat penting untuk olahragawan yang hendak bertanding dimana ia membutuhkan makanan yang dapat dengan cepat dikonversi menjadi energi. ${ }^{28}$

Maka untuk mengendalikan kadar glukosa darah dianjurkan mengonsumsi makanan dengan IG rendah. Disamping IG, BG makanan juga penting untuk diperhatikan. Tujuan BG yaitu menilai dampak konsumsi karbohidrat dengan memperhitungkan IG makanan. BG berbanding lurus dengan kandungan karbohidrat makanan. Semakin rendah kandungan karbohidrat semakin rendah BG maka semakin kecil suatu makanan yang disajikan memicu peningkatan kadar glukosa darah. $6,7,19$

Nilai indeks glikemik yang tinggi pada bahan pangan tidak langsung menunjukkan kecepatan peningkatan gula darah, tetapi ditentukan oleh kandungan karbohidrat yang disajikan. Bahan pangan dengan beban glikemik yang tinggi lebih mencerminkan peningkatan kadar glukosa darah, dibandingkan dengan nilai indeks glikemik yang 
tinggi. Konsumsi dalam jangka panjang terhadap bahan pangan yang memiliki nilai beban glikemik yang tinggi dapat dikaitkan dengan resiko penyakit DM tipe $2 .^{26}$

Beban glikemik makanan dapat dikelompokkan menjadi BG rendah $(<11)$, BG sedang (11-19), dan BG tinggi (>20). ${ }^{19}$ Beban glikemik roti tanpa substitusi tepung ampas kelapa sebesar 24,38; roti substitusi tepung ampas kelapa sebanyak $10 \%$ yaitu 14,81 ; dan roti substitusi tepung ampas kelapa sebanyak $20 \%$ yaitu 14,50 . Roti tanpa substitusi tepung ampas kelapa memiliki BG tinggi, sedangkan roti dengan substitusi tepung ampas kelapa sebanyak $10 \%$ dan 20\% memiliki BG sedang dengan BG terendah dimiliki oleh roti dengan substitusi tepung ampas kelapa sebanyak 20\%. Hal ini menunjukkan bahwa roti yang disubstitusikan dengan tepung ampas kelapa lebih sedikit menaikkan kadar glukosa darah dibandingkan roti tanpa substitusi tepung ampas kelapa, dimana semakin banyak substitusi tepung ampas kelapa terhadap roti akan semakin menurunkan BG roti sehingga lebih sedikit menaikkan glukosa darah.

Roti tanpa substitusi tepung ampas kelapa memiliki IG sedang dan BG tinggi, sedangkan roti dengan substitusi tepung ampas kelapa memiliki IG rendah dan BG sedang. Hal ini menunjukkan bahwa lebih baik mengonsumsi roti yang disubstitusi tepung ampas kelapa dengan mengurangi porsi penyajiannya $(<30 \mathrm{~g})$.

\section{Uji Tingkat Kesukaan}

Roti merupakan makanan padat yang bertekstur lembut dan merupakan salah satu jenis makanan yang berbentuk sponge, yaitu makanan yang sebagian besar volumenya tersusun dari gelembung-gelembung gas ${ }^{17}$. Hasil uji tingkat kesukaan terhadap warna, aroma, tekstur, dan rasa menunjukkan roti dengan substitusi tepung ampas kelapa memiliki tingkat kesukaan yang lebih rendah dibandingkan roti tanpa substitusi tepung ampas kelapa. Roti dengan substitusi tepung ampas kelapa sebanyak $10 \%$ masih disukai oleh panelis, namun untuk tekstur roti kesukaan panelis mulai berkurang walaupun masih dalam kategori netral. Warna, tekstur, dan rasa roti dengan substitusi tepung ampas kelapa sebanyak $20 \%$ masuk dalam kategori netral, sedangkan untuk aromanya masih disukai oleh panelis.

Hasil uji statistik Friedman menunjukkan bahwa terdapat pengaruh substitusi tepung ampas kelapa terhadap warna, tekstur, dan rasa roti, sedangkan pada aroma tidak ada pengaruh yang bermakna. Tepung ampas kelapa memiliki aroma yang harum khas kelapa sehingga mengakibatkan roti yang disubstitusikan dengan tepung ini pun memiliki aroma yang harum khas kelapa ${ }^{8}$. Hal ini menyebabkan aroma roti yang disubstitusikan dengan tepung ampas kelapa masih disukai oleh panelis.

Roti dengan substitusi tepung ampas kelapa memiliki warna yang semakin putih dibandingkan dengan roti tanpa substitusi tepung ampas kelapa. Warna yang semakin putih ini tampak lebih pucat apabila dibandingkan dengan roti tanpa substitusi tepung ampas kelapa yang memiliki warna kuning kecokelatan, sehingga panelis cenderung lebih menyukai roti tanpa substitusi tepung ampas kelapa yang memiliki warna lebih menarik. Warna roti yang semakin pucat mungkin disebabkan karena kelebihan waktu pengadukan adonan yang disebut over mixing dan karena tepung ampas kelapa memiliki derajat putih yang lebih tinggi dibandingkan tepung terigu ${ }^{8,24}$. Tingginya derajat putih tepung ampas kelapa disebabkan karena adanya perlakuan blanching dan perendaman dengan larutan $\mathrm{NaCl} 3 \%$ yang juga dapat mencegah reaksi pencokelatan (enzymatic browning $)^{8}$.

Tekstur roti yang disubstitusikan dengan tepung ampas kelapa akan semakin padat dan berserat seiring dengan semakin banyaknya tepung ampas kelapa yang disubstitusikan. Semakin banyak tepung ampas kelapa yang disubstitusikan akan mengakibatkan rendahnya kandungan gluten yang terkandung dalam tepung terigu. Gluten mempunyai sifat fisik yang elastis dan dapat mengembang. Rendahnya kandungan gluten mengakibatkan rongga-rongga adonan yang terbentuk hanya sedikit sehingga roti yang dihasilkan bertekstur padat dan kurang mengembang. Di samping itu, tepung ampas kelapa juga memiliki kandungan serat yang tinggi sehingga semakin banyak tepung ampas kelapa yang disubstitusikan akan mengakibatkan tekstur yang sangat berserat. ${ }^{25}$

Rasa yang dihasilkan dari roti substitusi tepung ampas kelapa sebenarnya cukup enak karena tepung ampas kelapa yang disubstitusikan memberi tambahan cita rasa kelapa yang gurih. Namun, seperti yang telah dijelaskan sebelumnya, tepung ampas kelapa memiliki kandungan serat yang sangat tinggi sehingga penambahan substitusi tepung ampas kelapa yang semakin banyak akan menimbulkan rasa berpasir yang diakibatkan karena kandungan seratnya yang tinggi sehingga kesukaan panelis terhadap rasa roti yang 
disubstitusikan dengan tepung ampas kelapa ini juga semakin berkurang. ${ }^{25}$

\section{SIMPULAN}

1. Roti substitusi $20 \%$ tepung ampas kelapa memiliki indeks glikemik rendah yaitu sebesar $39,85 \%$ dan beban glikemik sedang yaitu sebesar 14,50, semakin banyak tepung ampas kelapa yang disubstitusikan pada roti maka indeks glikemik dan beban glikemik roti akan turun.

2. Uji tingkat kesukaan terhadap warna, aroma, tekstur, dan rasa pada roti yang disubstitusikan dengan tepung ampas kelapa memiliki nilai yang lebih rendah dibandingkan dengan roti tanpa substitusi tepung ampas kelapa.

\section{SARAN}

Roti yang direkomendasikan adalah roti substitusi $10 \%$ tepung ampas kelapa yang memiliki IG rendah dan BG sedang, serta nilai kesukaan yang lebih diterima dibandingkan roti substitusi $20 \%$ tepung ampas kelapa.

\section{DAFTAR PUSTAKA}

1. Sudoyo, Aru W. et al. 2006. Buku Ajar Ilmu Penyakit Dalam Edisi IV Jilid III. Jakarta: Pusat Penerbitan Departemen Ilmu Penyakit Dalam Fakultas Kedokteran Universitas Indonesia.

2. Kementrian kesehatan republik indonesia. Prevalensi Diabetes Melitus Di Indonesia. 2007. URL: http://www.depkes.go.id. Diakses pada tanggal 29 Mei 2013.

3. Marion JF. 2008. Diabetes mellitus and Hypoglycemia of Nondiabetic Origin. In: Mahan LK, Escott-stump S. Krause's Food, Nutrition, and Diet Therapy $13^{\text {th }}$ Edition. Philadelphia: WB Saunders Company. Pages 676-710.

4. Trinidad, Trinidad P. Et al. 2003. Glycaemic Index of Different Coconut (Cocos nucifera)-Flour Products in Normal and Diabetic Subjects. British Journal of Nutrition (2003), 90, 551-556.

5. Wolever TM, Mehling C, Chiasson JL, et al. 2008. Low glycaemic index diet and disposition index in type 2 diabetes (the Canadian Trial of Carbohydrates in Diabetes): a randomised controlled trial. Diabetologia. 2008;51:16071615.

6. Beber Serena. Diabetes and nutrition: The role of carbohydrates and the glycemic index. Diabetes Care News 2004; 18: 11-3.

7. Rimbawan \& Albiner Siagian. Indeks Glikemik Pangan Cara Mudah Memilih Pangan yang Menyehatkan. 2004. Jakarta: Penebar Swadaya.

8. Putri, Meddiati Fajri. 2010. Kandungan Gizi dan Sifat Fisik Tepung Ampas Kelapa sebagai Bahan
Pangan Sumber Serat. TEKNUBUGA Vol 2. No. 2 - April 2010.

9. Kailaku, Sari Intan, Ira Mulyawanti, Kun Tanti Dewandari, \& Andi Nur Alam Syah. Potensi Tepung Kelapa dari Ampas Industri Pengolahan Kelapa. Balai Besar Penelitian dan Pengembangan Pascapanen Pertanian.

10. International Commission on Microbiological Specifications for Foods (ICMSF). 2003. Microorganisms in Foods 5: Characteristics of Microbial Pathogens. United Kingdom: Biddles/IBT Global.

11. RA, Garcia, Hotchkiss JH, \& Steinkraus KH. 1999. The Effect of Lipids on Bongkrekic (Bongkrek) Acid Toxin Production by Burkholderia cocovenenans in Coconut Media. Food Addit Contam. 1999 Feb;16(2):63-9.

12. Jiao, Zhenquan, et al. 2003. Need to differentiate Lethal Toxin-Producing Strains of Burkholderia gladioli, Which Cause Severe Food Poisoning: Description of B. gladioli Pathovar cocovenenans and an Emended Description of B. gladioli. Microbiol. Immunol., 47(12), 915-925, 2003.

13. Handoko, Heryadi Suryanto. 1989. Pengaruh Asam Laktat dan Asam Asetat terhadap Pertumbuhan Pseudomonas cocovenenans dan Produksi Toksoflavin dalam Pembuatan Tempe Bongkrek. Fakultas Teknologi Pertanian Institut Pertanian Bogor.

14. Fathonah, Siti. 2005. Higiene dan Sanitasi Makanan. Fakultas Teknik Universitas Semarang.

15. S.P.Ng, C.P. Tan, O.M.Lai, K.Long, and H. Mirhosseini. 2010. Extraction and characterization of dietary fiber from coconut residue. Journal of Food, Agriculture \& Environment Vol.8 (2): 172-177. 2010.

16. Trinidad et al. 2006. Dietary fiber from coconut flour: A functional food. Innovative Food Science and Emerging Technologies 7 (2006) 309-317.

17. Mudjajanto, E.S dan L.N. Yulianti. 2007. Seri Agrotekno Membuat Aneka Roti. Jakarta: Swadaya.

18. Brouns F., I. Bjorck, K. N. Frayn, A. L. Gibbs5, V. Lang, G. Slama \& T. M. S. Wolever. 2005. Glycaemic Index Methodology. Nutrition Research Reviews (2005), 18, 145-171.

19. Ningrum, Dhini Rahayu, Fatma Zuhrotun Nisa', \& Retno Pangastuti. Indeks Glikemik dan Beban Glikemik Sponge Cake Sukun sebagai Jajanan Berbasis Karbohidrat pada Subyek Bukan Penyandang Diabetes Mellitus. Prosiding Seminar Nasional: Food Habit and Degenerative Diseases.

20. Adha, Hijrah Mutiara. 2012. Indeks Glikemik dan Beban Glikemik Sukun dengan Berbagai Macam Pengolahan [Skripsi]. Yogyakarta: Fakultas Kedokteran UGM; 2012.

21. Rahayu WR. Penuntun praktikum penilaian organoleptik. Bogor : Jurusan Teknologi Pangan 
dan Gizi Fakultas Teknologi Pertanian Institut Pertanian Bogor; 2001.h.29-30.

22. Civille G, Meilgard M, Carr BT. Sensory evaluation techniques. 3rd ed. Florida : CRC; 1999.p.8-11.

23. Dahlan, MS. 2011. Statistik untuk Kedokteran dan Kesehatan. Salemba Medika.

24. Widodo Richardus, Wahyudi H. 2007. Pengaruh Substitusi Parsial Tepung Terigu dengan Tepung Pati Gayong dan Penambahan Sodium Stearoyl-2 lactylat terhadap mutu roti tawar.

25. Roza, Yulia. 2009. Pengaruh Campuran Tepung Jagung dan Tepung Ampas Kelapa terhadap Karakteristik Cookies yang Dihasilkan [Skripsi]. Padang: Fakultas Teknologi Pertanian Universitas Andalas; 2009.

26. Foster-Powell, K. Holt, S. H. A., dan BrandMiller, J. C. 2002. International table of glycemic index and glycemic load values. Am J Clin Nutr., vol. 76, hal. 5-56.

27. Lu ZX, Walker KZ, Muir JG, O’Dea K. 2004. Arabinoxylan fiber improves metabolic control in people with type II diabetes. Eur J Clin Nutr. 2004;58:621-628.

28. Indrasari, Siti Dewi, E. Y. Purwani, P. Wibowo, \& Jumali. 2008. Nilai Indeks Glikemik Beras Beberapa Varietas Padi. Penelitian Pertanian Tanaman Pangan Vol. 27 No. 32008. 